\title{
Current aspects of spontaneous pneumothorax
}

\author{
F.M.N.H. Schramel*, P.E. Postmus**, R.G.J.R.A. Vanderschueren*
}

Current aspects of spontaneous pneumothorax. F.M.N.H. Schramel, P.E. Postmus, R.G.J.R.A. Vanderschueren. (CERS Journals Ltd 1997.

ABSTRACT: Although spontaneous pneumothoraces have been recognized and treated for almost 180 yrs, new aspects have emerged concerning pathogenesis, diagnostic procedures and treatment modalities.

In spite of the fact that blebs and bullae are frequently found in patients with primary spontaneous pneumothorax, they seldom seem to be the actual cause of the pneumothorax. Inflammatory changes in the distal airways play an important role in the occurrence of the pneumothorax during transpulmonary pressure changes.

The value of the routine use of additional expiratory chest radiographs in diagnosing pneumothoraces has been doubted in previous studies. In this review, the diagnostic yield from additional expiratory chest radiographs is analysed. The role of previous pneumothoraces at presentation and the presence of blebs and bullae are discussed in predicting future recurrences and choosing appropriate treatment for optimal cost-effectiveness. Recommendations are made regarding treatment of primary and secondary spontaneous pneumothorax.

Eur Respir J 1997; 10: 1372-1379.
*Dept of Pulmonary Diseases, St. Antonius Hospital, Nieuwegein, The Netherlands. **Free University Hospital, Amsterdam, The Netherlands.

Correspondence: F.M.N.H. Schramel

Dept of Pulmonary Diseases

St. Antonius Hospital

PO Box 2500

3430 EM Nieuwegein

The Netherlands

Keyword: Spontaneous pneumothorax

Received: April 301996

Accepted after revision September 51996
Pneumothorax is defined as the presence of air in the pleural cavity [1]. As early as 1819, LAENNEC [2] described the symptoms and signs of a patient with a pneumothorax. Although most pneumothoraces were then caused by tuberculosis, he also found pneumothoraces during autopsies of patients with apparently healthy lungs; he named these "pneumothorax simple".

\section{Aetiology and pathogenesis}

Today, pneumothoraces are divided into spontaneous pneumothorax, occurring without a preceding event, and traumatic pneumothorax, due to direct or indirect trauma. Iatrogenic pneumothoraces, resulting from diagnostic or therapeutic medical procedures, are also categorized as traumatic pneumothoraces.

Spontaneous pneumothoraces are divided into primary and secondary spontaneous pneumothoraces. Secondary spontaneous pneumothoraces are associated with underlying pulmonary pathology, usually chronic obstructive pulmonary disease (COPD). Acquired immune deficiency syndrome (AIDS) and Pneumocystis carinii infections appear to play an increasing role in the aetiology of secondary spontaneous pneumothoraces [3].

No underlying pulmonary disease is present in patients with primary spontaneous pneumothorax. However, blebs and bullae seem to play a role in the pathogenesis, since they are frequently found during thoracoscopy, thoracotomy or sternotomy (table 1). Thoracoscopic studies have shown the presence of blebs and bullae in $48-79 \%$ of patients with unilateral primary spontaneous pneumo-thorax [4-8]. With the development of video-assisted techniques, the recognition of blebs and bullae during thoracoscopy has improved. In more than $76 \%$ of patients,

Table 1. - Occurrence of blebs and bullae in patients with primary spontaneous pneumothorax, detected during thoracoscopy, video-assisted thoracoscopy, thoracotomy and sternotomy

\begin{tabular}{|c|c|c|c|c|c|}
\hline $\begin{array}{l}\text { First } \\
\text { author }\end{array}$ & Year & [Ref.] & $\begin{array}{c}\text { Pts } \\
n\end{array}$ & Treatment & $\begin{array}{c}\text { Blebs } \\
\text { and bullae } \\
\%\end{array}$ \\
\hline SWIERENGA & 1955 & [4] & 33 & $\mathrm{~T}$ & 79 \\
\hline WAGENAAR & 1970 & [5] & 136 & $\mathrm{~T}$ & 60 \\
\hline VANDERSCHUEREN & 1981 & [6] & 126 & $\mathrm{~T}$ & 48 \\
\hline VD BREKEL & 1993 & [7] & 622 & $\mathrm{~T}$ & 59 \\
\hline Boutin & 1995 & [8] & 137 & $\mathrm{~T}$ & 58 \\
\hline NKERE & 1991 & [9] & 60 & VAT & 85 \\
\hline HAZELRIGG & 1993 & [10] & 26 & VAT & 100 \\
\hline INDERBITZI & 1994 & [11] & 57 & VAT & 84 \\
\hline SCHRAMEL & 1995 & [12] & 97 & VAT & 76 \\
\hline BARONOFSKY & 1957 & [13] & 26 & $\mathrm{TT}$ & $\begin{array}{c}96 \\
\left(96^{*}\right)\end{array}$ \\
\hline GoBeL & 1963 & [14] & 27 & TT & 100 \\
\hline HAGEN & 1987 & [15] & 60 & TT & 93 \\
\hline IKEDA & 1988 & [16] & 29 & ST & $\begin{array}{c}93 \\
(79 *)\end{array}$ \\
\hline Donahue & 1993 & [17] & 83 & TT & 94 \\
\hline
\end{tabular}

Pts: patients; T: thoracoscopy; TT: thoracotomy; ST: median sternotomy; VAT: video-assisted thoracoscopy. *: Blebs and bullae on the contralateral side.

Previous articles in this series: No. 1: G. Miserocchi. Physiology and pathophysiology of pleural fluid turnover. Eur Respir J 1997; 10: 219-225. No. 2: R.W. Light. Diagnostic principles in pleural disease. Eur Respir J 1997; 10: 476-481. No. 3: G.T. Kinasewitz. Transudative effusions. Eur Respir J 1997; 10: 714-718. No. 4: J. Ferrer. Pleural tuberculosis. Eur Respir J 1997; 10: 942-947. No. 5: H. Hamm, R.W. Light. Parapneumonic effusion and empyema. Eur Respir J 1997; 10: 1150-1156. No. 6: G. Hillerdal. Chylothorax and pseudochylothorax. Eur Respir J 1997; 10: 1157-1162. 
blebs and bullae were detected during video-assisted thoracoscopy (VAT) [9-12]. Surgical studies have shown blebs and bullae in almost all patients during thoracotomy or sternotomy [13-17]. Two studies have described bilateral surgical therapy in patients with unilateral spontaneous pneumothorax, demonstrating blebs and bullae on the contralateral side in $79-96 \%$ of the patients $[13$, $16]$.

Bilateral presence of blebs and bullae in patients with unilateral primary spontaneous pneumothorax has also been demonstrated with thoracic computed tomography (CT). On CT, blebs and bullae are designated as emphysema-like changes (ELCs). ELCs were found in $89 \%$ of patients on the ipsilateral side and in up to $80 \%$ on both sides $[18,19]$. In the control group, consisting of healthy volunteers matched for age and smoking behaviour, ELCs were found in $20 \%$ of individuals [19]. ELCs were also found in $81 \%$ of patients with healed primary spontaneous pneumothorax, who had never smoked, in contrast to none of the controls who had never smoked [20]. Therefore, ELCs appear to be related to the occurrence of primary spontaneous pneumothorax.

Several theories exist regarding the development of ELCs in patients with primary spontaneous pneumothorax. As in centriacinar emphysema, the formation of ELCs in primary spontaneous pneumothorax is associated with the degradation of elastic fibres [21]. The elastolysis is caused by the imbalance between proteases and antiproteases and between oxidants and antioxidants, in which neutrophils and macrophages play an important part [22-24]. The respiratory bronchiolitis caused by the influx of these inflammatory cells, as in smokers, is closely associated with bronchiolar wall fibrosis and destruction of the pulmonary parenchyma, resulting in ELCs [25]. Bronchoalveolar lavage (BAL) in patients with primary spontaneous pneumothorax showed a close relationship between the total cell count, especially macrophages, in the BAL fluid and the extent of ELCs both in the affected and the nonaffected lung [26]. However, no study has demonstrated that ELCs are the actual cause of primary spontaneous pneumothorax.

Another fact that strengthens the hypothesis that inflammatory changes play an important role in the pathogenesis of primary spontaneous pneumothorax is the fact that smoking is related to a ninefold increase of relative risk of contracting a pneumothorax among females and a 22 fold increase of relative risk in males, with a dose-response relationship between the number of cigarettes smoked per day and the occurrence of primary spontaneous pneumothorax [27]. Numerous studies have demonstrated increased numbers of inflammatory cells, especially macrophages, in the small airways of smokers [28, 29]. These macrophages release potent chemotactic factors, resulting in accumulation of neutrophils in the small airways [28]. The influx of neutrophils is also enhanced by loss of functional activity of chemotactic factor inactivator due to the cigarette smoke itself [30].

The inflammatory changes in the distal airways of smokers suggest that endobronchial obstruction is part of the pathogenesis of primary spontaneous pneumothorax. Endobronchial obstruction due to accumulation of inflammatory cells between the pulmonary parenchyma and the bronchial tree can induce overpressure in alveolar tissue, resulting in rupture of pulmonary parenchyma. This is supported by the fact that changes in the transpulmonary pressure are related to increased incidence of pneumothorax in fighter pilots and divers [31, 32]. However, less excessive transpulmonary pressure chang-es also induce pneumothoraces. Atmospheric pressure changes of at least $1 \mathrm{kPa}$ are associated with an increased incidence of spontaneous pneumothorax [33, 34].

It remains unclear whether ELCs are the sites of rupture, because, according to Boyle's law, during a rise or fall of intrapulmonary pressure, pressure changes inside ELCs will be smaller than in normal alveolar tissue due to the larger cubic capacities of ELCs.

Histopathological and electron microscopic analysis of tissue obtained during bullectomy in patients with spontaneous pneumothorax have revealed obstruction and stenosis of the distal airways due to bronchial wall inflammation and peribronchial fibrosis $[35,36]$. These findings suggest an obstruction check-valve mechanism as the cause of spontaneous pneumothorax. In these studies, communications between pleural cavity and ELCs were not seen, although some types of bullae exhibited a marked absence of mesothelial cells [37]. Therefore, the site of rupture of the visceral pleura appears to be located outside ELCs.

\section{Diagnosis}

Spontaneous pneumothorax is usually suggested by clinical history and physical examination. Radiological investigation of the chest is needed to establish the diagnosis. Currently, it is common practice to perform chest radiographs during maximal inspiration and expiration in patients suspected of a pneumothorax. Two studies have been published evaluating the value of routine use of additional expiratory chest radiographs in diagnosing pneumothoraces. All pneumothoraces were seen by two observers on inspiratory chest radiographs in 79 patients with spontaneous pneumothorax [38]. Two out of four observers missed one small apical pneumothorax on an inspiratory chest radiograph, when evaluating 128 chest radiographs, consisting of 100 paired inspiratory and expiratory chest radiographs with proven pneumothoraces and 28 normal chest radiographs [39]. If expiratory chest radiographs have additional value in diagnosing pneumothoraces, this should be especially so in difficult situations, such as in small apical pneumothoraces.

Several explanations are possible for the potential beneficial effects of expiration in detecting small apical pneumothoraces on chest radiographs in the upright position. A relative enlargement of the pneumothorax in relation to the size of the thoracic cage might occur during expiration. External compression of lung tissue during expiration could result in thickening of the visceral pleura and enhanced contrast between intrapleural air and pulmonary parenchyma. This last explanation appears to be invalid. During expiration, the density of collapsed lung tissue is not altered [40]. However, the density of the extrapulmonary tissue is increased during expiration, resulting in increased radiation exposure as monitored by the ionization chambers of standard radiological equipment. Increased radiation exposure resulted in increased blackening of the collapsed lung on expiratory chest 
radiographs [41]. No difference in contrast was found between pulmonary tissue and intrapleural air on inspiratory and expiratory chest radiographs [41]. From these findings, one may conclude that the routine addition of expiratory chest radiographs does not improve the diagnostic yield from inspiratory chest radiographs in patients suspected of having a pneumothorax. It therefore seems justified to confine the radiological investigation to inspiratory chest radiographs. Moreover, inspiratory chest radiographs are needed to investigate other possible causes of the patient's complaints, such as pulmonary effusions or parenchymal consolidations.

\section{Recurrences}

The average rate of absorption of air from the pleural cavity is slow. In a study of 11 patients with pneumothoraces ranging 16-100\% of collapsed lung in size, the mean rate of re-expansion was $1.8 \%$ per day, resulting in full re-expansion of the collapsed lung after 7 weeks (mean 3.2 weeks) [42]. Therefore, only patients with a pneumothorax $<15 \%$ of the hemithorax in size can be successfully subjected to this kind of conservative treatment [1]. The recurrence rate of primary spontaneous pneumothorax treated with observation was 32\% [43]. Since a minority of patients with primary spontaneous pneumothorax have small pneumothoraces, most patients are treated with invasive procedures [5, 43].

Needle aspiration or tube drainage will have the smallest influence upon the natural course of primary spontaneous pneumothorax because conditions in the pleural cavity will only be slightly altered. A survey of several studies (table 2) shows that the mean recurrence rate of primary spontaneous pneumothorax treated with bedrest, needle aspiration, or tube drainage was $30 \%$, ranging $16-52 \%$ [43-52]. The majority of recurrences appeared within 6 months to 2 yrs $[49,50]$, although other studies could not confirm this finding [45, 47].

Several studies have been performed concerning possible relationships between patient characteristics, pulmonary disease, and the development of recurrences. Independent risk factors for recurrence in 122 patients with primary spontaneous pneumothorax were reported to be: pulmonary fibrosis detected on chest radiographs; physical characteristics; smoking behaviour; and age [50]. However, no association could be demonstrated between recurrence rate and COPD in 303 patients with primary and secondary spontaneous pneumothorax [53]. In 35 patients with primary spontaneous pneumothorax, who underwent thoracic CT scanning, the presence of ELCs had no predictive value for recurrences during follow-up [18]. No differences in presence of ELCs detected during VAT could be found in patients with first time primary spontaneous pneumothorax and recurrent spontaneous pneumothorax [54].

From these findings, one can conclude that the presence of ELCs in patients with primary spontaneous pneumothorax has no predictive value for the future development of recurrences. Therefore, investigations in order to diagnose ELCs should not influence the choice of treatment to prevent recurrences.

\section{Pulmonary function tests}

In the past, several studies have reported various results concerning the analysis of pulmonary function parameters in patients treated for primary spontaneous pneumothorax [55-58]. Almost all patients were treated with tube drainage. Since the patients had no previous pulmonary complaints, none of the studies described pulmonary function test parameters before the onset of the pneumothoraces.

The main issue in these studies concerned the question of whether patients with primary spontaneous pneumothorax had physiological evidence of emphysema. Although emphysema is a histopathological diagnosis, pulmonary function criteria, such as decreased diffusing capacity, reduced retractive force and increased total lung capacity, are known to correlate with emphysema [59].

Decreased diffusing capacity parameters have been reported in healthy smokers, caused by decrease of the gas-exchange surface due to destruction of alveolar walls [60]. Reduced diffusing capacity was found in $25-86 \%$ of patients with primary spontaneous pneumothorax [55-58]. More than 70\% of the patients were smokers. The reduced diffusing capacity reflected the loss of alveolar surface, which is expressed by ELCs [57]. In previous reports, $10 \%$ of patients with primary spontaneous pneumothorax met all of the pulmonary function criteria of emphysema [55-58]. The mean age of these patients ranged 28-32 yrs, which is the lower limit of the age distribution at which emphysema becomes apparent [61]. The discrepancy between the minimal pulmonary

Table 2. - Recurrence rates of patients with primary spontaneous pneumothorax, treated with bed-rest, needle aspiration or tube drainage

\begin{tabular}{|c|c|c|c|c|c|c|}
\hline $\begin{array}{l}\text { First } \\
\text { author }\end{array}$ & Year & [Ref.] & $\begin{array}{c}\text { Pts } \\
\mathrm{n}\end{array}$ & Treatment & $\begin{array}{l}\text { Recurrence rate } \\
\%\end{array}$ & $\begin{array}{c}\text { Follow-up } \\
\text { yrs }\end{array}$ \\
\hline HYDE & 1963 & [44] & 200 & BR, NA, TD & 27 & $?$ \\
\hline GoBEL & 1963 & [14] & 110 & BR, NA, TD & 52 & 6 \\
\hline RUCKLEY & 1966 & {$[45]$} & 175 & BR, NA, TD & 16 & $1-4$ \\
\hline SerEMETIS & 1970 & [46] & 154 & BR, TD & 41 & $>2$ \\
\hline O'ROURKE & 1989 & [43] & 148 & BR, TD & 25 & 6.3 \\
\hline Almind & 1989 & [47] & 34 & TD & 31 & 4.6 \\
\hline LIGHT & 1990 & [48] & 108 & $\mathrm{TD}$ & 41 & 2.4 \\
\hline LIPPERT & 1991 & [49] & 122 & $\mathrm{TD}$ & 29 & 10 \\
\hline BTSRC & 1993 & {$[50]$} & 65 & NA, TD & 23 & 1 \\
\hline HARVEY & 1994 & [51] & 65 & NA, TD & 23 & 1 \\
\hline ANDRIVET & 1995 & {$[52]$} & 61 & NA, TD & 21 & 0.25 \\
\hline Total & & & 1242 & BR, NA, TD & 30 & \\
\hline
\end{tabular}

Pts: patients; BR: bed-rest; NA: needle aspiration; TD: tube drainage; BTSRC: British Thoracic Society Research Committee. 
function abnormalities and the macroscopic findings of ELCs might be explained by the limitations of pulmonary function testing. The patients are not old enough to show physiological signs of emphysema, since previous reports demonstrated that ageing resulted in a homogeneous enlargement of the alveolar airspaces [62]. These changes preceded emphysema and were responsible for loss of lung elasticity.

A follow-up study over several decades, analysing pulmonary function parameters of patients with spontaneous pneumothorax and healthy volunteers, will be needed to determine whether more patients with spontaneous pneumothorax will develop clinical emphysema than the healthy volunteers.

\section{Treatment}

\section{General considerations}

Debate continues regarding the best management of primary spontaneous pneumothorax. Evacuation of air from the pleural cavity and the prevention of future recurrences are the primary goals of treatment. Numerous therapeutic options are available, ranging from observation to posterolateral thoracotomy with bullectomy and pleurectomy [1]. Invasive procedures are needed if the size of the pneumothorax exceeds $15 \%$ of the volume of the hemithorax, or if the pneumothorax is progressive over time.

Today, choice of treatment depends on the patient's presentation with a first time or recurrent spontaneous pneumothorax, the size of the pneumothorax, and the presence and extent of ELCs [1, 7, 8].

However, as mentioned previously in this review, the presence of ELCs in patients with primary spontaneous pneumothorax has no predictive value for the future development of recurrences and, therefore, should not influence the choice of treatment.

A recurrent spontaneous pneumothorax is one of the indications to perform more invasive therapy, such as pleural drainage with chemical pleurodesis, or even a surgical intervention. This is based on the assumption that the recurrence rate increases after previous pneumothoraces [14]. However, differences in recurrence rates after first time (57\%) and second time pneumothoraces $(62 \%)$, as well as after third time pneumothoraces $(83 \%)$, were not statistically significant, in contrast to differences between first and third time pneumothoraces $(p=0.04)$ [14]. Since the average time interval between the first time and the third time pneumothorax was $5 \mathrm{yrs}$, it is possible that recurrent spontaneous pneumothorax was not the risk factor for contracting a subsequent pneumothorax, but rather the age of the patient. Age has proved to be one of the predictors for future recurrences [49].

Therefore, the choice of treatment must not depend on the presence of ELCs or presentation with first time or recurrent spontaneous pneumothorax, but on the effectiveness of the treatment.

Several other factors, such as morbidity and the availability and costs of therapeutic options available in the clinic, are also of importance in making the right choice. Currently, cost-effectiveness is becoming increasingly important in the choice of treatment.

\section{Chemical pleurodesis}

Needle aspiration, tube drainage and the use of a Heimlich flutter valve have proved to be safe procedures in the treatment of primary spontaneous pneumothorax, with minor side-effects [14, 44-52]. However the mean ipsilateral recurrence rate of $30 \%$ was rather high. Chemical pleurodesis was shown to decrease the ipsilateral recurrence rate. In a prospective, multicentre, randomized clinical trial of 229 patients with spontaneous pneumothorax, tetracycline reduced the recurrence rate to $25 \%$, compared to tube drainage with a recurrence rate of $41 \%$ [48]. In several other studies, tetracycline also resulted in effective pleurodesis, with average recurrence rates of $9-16 \%[8,63,64]$. Intrapleural instillation of tetracycline induces the release of cytokines (interleukin-6, interleukin-8, tumour necrosis factor), which are markers of inflammatory response and attract neutrophils into the pleural space, resulting in pleural symphysis [65].

A good alternative is talc-suspension, also known as talc slurry. In a randomized prospective study of 96 patients, pleurodesis by talc slurry resulted in the lowest recurrence rate of $8 \%$, compared to $13 \%$ with tetracycline and $36 \%$ with simple tube drainage [47].

More commonly, talc is used by means of poudrage during thoracoscopy. Thoracoscopy can be performed by one port of entry with direct vision through a rigid telescope [4-7]. During the last few years, new imaging and video-techniques have become available, making thoracoscopy with a video-camera and multiple ports of entry possible [66]. Four to six grams of talc is insufflated by means of a talc atomizer or a disposable single-use spray canister. From recent reviews and several other following reports, a recurrence rate of $8 \%$ was found in 1,030 patients [8, 12,67-69]. Pleural symphysis is achieved by increased activation of pleural coagulation, expressed by increased production of antithrombin III complex and plasminogen activator inhibitor, and by decreased pleural fibrinolytic activity expressed by decreased levels of the degradation product of crosslinked fibrin (D-dimer) [70].

There has been some doubt about the safety of pleurodesis with talc, especially with talc slurry. Two cases have been reported with acute pneumonitis and adult respiratory distress syndrome (ARDS) after the administration of talc slurry [71, 72]. This rare complication occurred when a large amount of talc (more than $10 \mathrm{~g}$ ) was administered [71], or when vascular injury was present [72]. Others have suggested that it might be due to re-expansion oedema after the procedure [67].

Minimal long-term side-effects have been demonstrated with talc poudrage, with no major effect on the lung parenchyma, little impairment of pulmonary function, and pleural thickening on chest radiographs [57]. No mesothelioma was found in two studies following patients for 18-35 yrs after pleurodesis with talc $[57,73]$.

\section{Surgical therapy}

Conventional surgical therapy consists of (limited) posterolateral thoracotomy with bullectomy and pleurectomy (table 3). Pleurectomy was used to treat recurrent spontaneous pneumothorax for the first time in 1956, in nine patients [74]. In the following years, partial pleurectomy or pleural abrasion became standard therapy, 
Table 3. - Conventional surgical treatment in patients with spontaneous pneumothorax

\begin{tabular}{|c|c|c|c|c|c|c|}
\hline $\begin{array}{l}\text { First } \\
\text { author }\end{array}$ & Year & [Ref.] & $\begin{array}{c}\text { Pts } \\
n\end{array}$ & Treatment & $\begin{array}{l}\text { Recurrence rate } \\
\%\end{array}$ & $\begin{array}{c}\text { Follow-up } \\
\text { yrs }\end{array}$ \\
\hline BARONOFSKY & 1957 & [13] & 17 & $\mathrm{~B}, \mathrm{PP}$ & 0 & 6 \\
\hline GoBeL & 1963 & [14] & 31 & $\mathrm{~B}, \mathrm{PP}$ & 0 & 5.5 \\
\hline AsKew & 1976 & [75] & 100 & PP & 1 & $?$ \\
\hline GERTZ & 1983 & [76] & 40 & PA & 2.5 & 10 \\
\hline WEEDEN & 1988 & [77] & 233 & PP & 0.4 & 4.7 \\
\hline NKERE & 1991 & [9] & 60 & PA & 2 & 2.6 \\
\hline ELFELDT & 1991 & [78] & 68 & $\mathrm{~B}, \mathrm{PP}$ & 0 & $?$ \\
\hline VD BREKEL & 1993 & [7] & 248 & $\mathrm{~B}, \mathrm{PP}$ & 3 & $?$ \\
\hline DONAHUE & 1993 & [17] & 83 & $\mathrm{~B}, \mathrm{PD}$ & 4 & 9.1 \\
\hline KRASNIK & 1993 & [79] & 97 & $\mathrm{~B}, \mathrm{PA}$ & 0 & 0.41 \\
\hline Total & & & 977 & & 1.5 & \\
\hline
\end{tabular}

Pts: patients; B: bullectomy; PP: partial pleurectomy; PA: pleural abrasion; PD: Pleurodesis.

especially for recurrent spontaneous pneumothorax, and resulted in average recurrence rates of $1 \%$ [9, 75-77]. Combined pleurectomy and bullectomy showed average recurrence rates of $2 \%[7,13,14,17,78,79]$. A few authors have recommended bilateral surgical therapy, because $15 \%$ of the patients receiving unilateral therapy developed a contralateral pneumothorax during the years after the initial treatment $[13,16]$.

Recently, there has been a rapid development of minimally invasive surgery, particularly in video-assisted thoracic surgery (VATS). VATS is performed in the operation room during general anaesthesia with double-lumen intubation. Multiple ports of entry are used to introduce rigid telescopes with video attachment and various other instruments. Pleurectomy and bullectomy can be performed by VATS.

Reviewing the results of VATS in 805 patients with spontaneous pneumothorax, the mean recurrence rate was $4 \%$ (table 4) [10-12, 80-91], which was higher than the mean recurrence rate of $1.5 \%$ after conventional surgical therapy (table 3) [7, 9, 13, 14, 17, 74-78]. However, several studies that have reported comparative analysis of VATS versus conventional thoracotomy have shown reduced operation time, drainage time and complication rates after VATS, resulting in shorter hospital stay and a more rapid return to the normal daily activities of the patients [84, 92, 93].
VATS has also proved to be more cost-effective compared to conservative treatment by observation or pleural drainage in patients with spontaneous pneumothorax. Irrespective of the presence of ELCs, drainage and hospitalization time were shorter and complication and recurrence rates were lower in patients with first time or recurrent spontaneous pneumothorax treated with VATS compared to conservative treatment. When costs due to the waiting time before VATS were excluded, the total costs of VATS were lower than the cost of conservative therapy [94].

Since the presence of ELCs and recurrent spontaneous pneumothorax at presentation are not predicting factors for future recurrences, it can be questioned whether VATS should be applied only in patients with recurrent or secondary spontaneous pneumothorax, as is the case in most studies. In 113 patients, mostly with recurrent spontaneous pneumothorax, univariate and multivariate analysis of clinical characteristics, such as age, smoking behaviour, presence of ELCs, pleurodesis and bleb ablation by stapling, showed that the resection of ELCs during VATS was the only predictor of future recurrences [88]. In a study of 97 patients, of which $73 \%$ were patients with first time spontaneous pneumothorax, similar multivariate analysis showed that the use of stapler devices during VATS was significantly associated with prolonged drainage time and hospital stay, but not with

Table 4. - Video-assisted thoracic surgery (VATS) in patients with spontaneous pneumothorax

\begin{tabular}{|c|c|c|c|c|c|c|}
\hline $\begin{array}{l}\text { First } \\
\text { author }\end{array}$ & Year & [Ref.] & $\begin{array}{c}\text { Pts } \\
\mathrm{n}\end{array}$ & Treatment & $\begin{array}{c}\text { Recurrence rate } \\
\%\end{array}$ & $\begin{array}{c}\text { Follow-up } \\
\text { yrs }\end{array}$ \\
\hline CANNON & 1993 & [80] & 19 & EG/PS & 10 & ? \\
\hline YAMAGUCHI & 1993 & [81] & 37 & EG & 2.7 & $?$ \\
\hline HAZELRIGG & 1993 & [10] & 26 & EG & 0 & $?$ \\
\hline INDERBITZI & 1994 & [11] & 72 & EG/EL/PS & 8.3 & 19.6 \\
\hline KAISER & 1994 & [82] & 23 & EG & 13 & $?$ \\
\hline THIES & 1994 & [83] & 31 & EG & 6 & 6 \\
\hline SCHIPPERS & 1994 & [84] & 25 & EG/PS & 4 & $?$ \\
\hline WALLER & 1994 & [85] & 30 & EG/PP & 7 & 15.1 \\
\hline ELFELDT & 1994 & [86] & 54 & EG & 4 & 11 \\
\hline ELLMAN & 1995 & [87] & 25 & EG/PP & 4 & 30 \\
\hline LIU & 1995 & [88] & 82 & EG/PD & 0 & 22 \\
\hline NAUNHEIM & 1995 & [89] & 121 & EG/PD & 4 & 13.1 \\
\hline YIM & 1995 & [90] & 114 & EG/EL/PS & 2 & 16 \\
\hline HÜRTGEN & 1995 & [91] & 49 & EG/PD & 2 & ? \\
\hline SCHRAMEL & 1995 & [12] & 97 & EG/PS & 4 & 24.2 \\
\hline Total & & & 805 & & 4 & \\
\hline
\end{tabular}

Pts: patients; EG: stapling with Endo-gastro-intestinal anastomosis (GIA) 3.0 Multifire (Autosuture; Zeist, the Netherlands); EL: Endo-loop; PS: pleural scarification; PP: partial pleurectomy; PD: pleurodesis. 
future recurrences [12]. From these findings, it may be concluded that it was not the presence of ELCs but the technique used to resect them that was responsible for the postoperative course and the occurrence of recurrent pneumothoraces.

First time or recurrent spontaneous pneumothorax showed no differences in postoperative outcome after VATS. In view of effectiveness, it is not justified to treat patients with first time spontaneous pneumothorax in a different and less effective way than patients with recurrent spontaneous pneumothorax.

\section{Treatment of secondary spontaneous pneumothorax}

Treatment options in primary and secondary spontaneous pneumothorax are similar. However, patients with secondary spontaneous pneumothorax are usually respiratorily compromised, necessitating rapid and effective treatment. In recent years, VATS has played an important role in the management of these patients [95]. Adequate pleurodesis with talc or partial pleurectomy can be performed. If VATS is not available in the clinic, thoracotomy is mandatory to achieve pleurodesis and, if necessary, oversew the airleak. Surgical removal of blebs and bullae appears to have a negative effect on the postoperative course due to prolongation of the airleakage [95]. However, ablation of bullae by neodymium-yttrium aluminium garnet (Nd-YAG) laser, carbon dioxide laser or argon beam laser showed a rapid sealing effect, which proved to be safe even in patients with severe bullous emphysema [96-98].

AIDS-related spontaneous pneumothorax is usually caused by Pneumocystis carinii infection and is difficult to treat. Treatment with tube thoracostomy has a high recurrence rate of $65 \%$ [1]. Effective treatment should be performed by chemical or surgical pleurodesis in combination with effective sealing of the air leakage by stapling, electrocautery or laser photocoagulation [99].

\section{Summary}

Several new aspects have emerged during the last 177 yrs, in which spontaneous pneumothoraces have been recognized and treated.

Blebs and bullae are related to the occurrence of primary spontaneous pneumothorax, but are seldom the actual cause of the pneumothorax. The obstruction check-valve mechanism due to inflammatory changes of the distal airways is responsible for the development of the pneumothorax during transpulmonary pressure changes.

For diagnosing pneumothoraces with radiography, the additional use of an expiratory chest radiograph is of no value. The natural course of primary spontaneous pneumothorax shows a mean recurrence rate of $30 \%$.

There is still no answer to the question of whether patients with spontaneous pneumothorax have (sub)clinical emphysema. The choice of treatment of spontaneous pneumothorax should not depend on the presence of ELCs or presentation with first time or recurrent spontaneous pneumothorax, but on the efficacy of the treatment. Pleurodesis by pleurectomy during video-assisted thoracoscopy shows the best results regarding cost-effectiveness in the management of primary and secondary spontaneous pneumothorax. Chemical pleurodesis with talc is a good alternative.

\section{References}

1. Light RW. Pneumothorax. In: Pleural Diseases. Baltimore, Williams \& Wilkins, 3rd Edn. 1995; pp. 242-277.

2. Laennec RTH. Du pneumothorax ou des épanchements aériformes dans la cavité pleurale: de l'auscultation médiate. Paris, 1819.

3. Wait MA, Esterera A. Changing clinical spectrum of spontaneous pneumothorax. Am J Surg 1992; 164: 528531.

4. Swierenga J, van Engelen W. De spontane pneumothorax. Ned Tijdsch Geneeskd 1955; 99: 2047-2053.

5. Wagenaar JPM. De zogenaamde idiopatische spontane pneumothorax. Thesis, Leiden, 1970.

6. Vanderschueren RGJRA. Le talcage pleural dans le pneumothorax spontané. Poumon Coeur 1981; 37: 273-276.

7. van de Brekel JA, Duurkens VAM, Vanderschueren RGJRA. Pneumothorax: results of thoracoscopy and pleurodesis with talc poudrage and thoracotomy. Chest 1993; 103: 345-347.

8. Boutin C, Astoul P, Rey F, Mathur PN. Thoracoscopy in the diagnosis and treatment of spontaneous pneumothorax. Clin Chest Med 1995; 16: 497-503.

9. Nkere UU, Griffin SC, Fountain SW. Pleural abrasion: a new method of pleurodesis. Thorax 1991; 46: 596-598.

10. Hazelrigg SR, Landreneau RJ, Mack M, et al. Thoracoscopic stapled resection for spontaneous pneumothorax. J Thorac Cardiovasc Surg 1993; 105: 389-393.

11. Inderbitzi RGC, Leiser A, Furrer M, Althaus U. Three years' experience in video-assisted thoracic surgery (VATS) for spontaneous pneumothorax. $J$ Thorac Cardiovasc Surg 1994; 107: 1410-1415.

12. Schramel FMNH, Sutedja TG, Janssen JP, Cuesta MA, v Mourik JC, Postmus PE. Prognostic factors in patients with spontaneous pneumothorax treated with videoassisted thoracoscopy. Diag Ther Endosc 1995; 2: 1-5.

13. Baronofsky ID, Warden HG, Kaufman JL, Whatley J, Hanner JM. Bilateral therapy for unilateral spontaneous pneumothorax. J Thorac Cardiovasc Surg 1957; 34: 1767-1769.

14. Gobel WG, Rhea WG, Nelson IA, Daniel RA. Spontaneous pneumothorax. J Thorac Cardiovasc Surg 1963; 46: 331-345.

15. Hagen RH, Reed W, Solheim K. Spontaneous pneumothorax. Scand J Thorac Cardiovasc Surg 1987; 21 : 183-185.

16. Ikeda M, Uno A, Yamane Y, Hagiwara N. Median sternotomy with bilateral bullous resection for unilateral spontaneous pneumothorax, with special reference to operative indications. J Thorac Cardiovasc Surg 1988; 96: 615-620.

17. Donahue DM, Wright CD, Viale G, Mathisen DJ. Resection of pulmonary blebs and pleurodesis for spontaneous pneumothorax. Chest 1993; 104: 1767-1769.

18. Mitlehner W, Friedrich M, Dissmann W. Value of computer tomography in the detection of bullae and blebs in patients with primary spontaneous pneumothorax. Respiration 1992; 59: 221-227.

19. Lesur O, Delorme N, Fromaget JM, Bernadac P, Polu JM. Computed tomography in the etiologic assessment of idiopathic spontaneous pneumothorax. Chest 1990; 98: 341-347.

20. Bense L, Lewander R, Eklund G, Odont D, Hedenstierna G, Wiman LG. Nonsmoking, non-alpha ${ }_{1}$-antitrypsin deficiency-induced emphysema in nonsmokers with healed spontaneous pneumothorax, identified by computed tomography of the lungs. Chest 1993; 103: 433-438. 
21. Fukuda Y, Haraguchi S, Tanaka S, Yamanaka N. Pathogenesis of blebs and bullae of patients with spontaneous pneumothorax: ultrastructural and immunohistochemical studies. Am J Respir Crit Care Med 1994; 149: A1022.

22. Tetely TD. Proteinase imbalance: its role in lung disease. Thorax 1993; 48: 560-565.

23. Wallaert B, Gressier B, Marquette $\mathrm{CH}$, et al. Inactivation

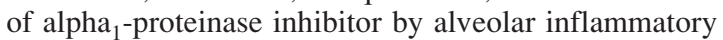
cells from smoking patients with or without emphysema. Am Rev Respir Dis 1993; 147: 1537-1543.

24. Kondo T, Tagami S, Yohioka A, Nishiruma M, Kawakami Y. Current smoking of elderly men reduces antioxidants in alveolar macrophages. Am Rev Respir Dis 1991; 143: 144-149.

25. Adesina AM, Vallyathan V, McQuillen EN, Weaver SO, Craighead JE. Bronchiolar inflammation and fibrosis associated with smoking: a morphologic cross-sectional population analysis. Am Rev Respir Dis 1991; 143: 144-149.

26. Schramel FMNH, Meyer CJLM, Postmus PE. Inflammation as cause of spontaneous pneumothorax and emphysematous-like changes: results of bronchoalveolar lavage. Eur Respir J 1995; 8, Suppl. 19: 397s.

27. Bense L, Eklund G, Odont D, Wiman LG. Smoking and the increased risk of contracting spontaneous pneumothorax. Chest 1987; 92: 1009-1012.

28. Hunninghake GW, Crystal RG. Cigarette smoking and lung destruction: accumulation of neutrophils in the lungs of cigarette smokers. Am Rev Respir Dis 1983; 128: 833-838.

29. Sibille Y, Reynolds HY. Macrophages and polymorphonuclear neutrophils in lung defense and injury: state of the art. Am Rev Respir Dis 1990; 141: 471-501.

30. Robbins RA, Gossman GL, Nelson KJ, Koyama S, Thompson AB, Rennard SI. Inactivation of chemotactic factor inactivator by cigarette smoke: a potential mechanism of modulating neutrophil recruitment to the lung. Am Rev Respir Dis 1990; 142: 763-768.

31. Dermksian G, Lamb LE. Spontaneous pneumothorax in apparently healthy flying personnel. Ann Intern Med 1959; 51: 39-51.

32. Weiss LD, van Meter KW. Cerebral air embolism in asthmatic scuba divers in a swimming pool. Chest 1995 ; 107: 1653-1654.

33. Bense L. Spontaneous pneumothorax related to falls in atmospheric pressure. Eur J Respir Dis 1984; 65: 544-546.

34. Scott GC, Berger R, McKean HE. The role of atmospheric pressure variation in the development of spontaneous pneumothoraces. Am Rev Respir Dis 1989; 139: 659-662.

35. Lichter I, Gwynne JF. Spontaneous pneumothorax in young subjects: a clinical and pathological study. Thorax 1971; 26: 409-417.

36. Tueller EE, Crise R, Belton JC, McLaughlin RF. Idiopathic spontaneous pneumothorax: electron-microscopic study. Chest 1977; 71: 419-421.

37. Ohata M, Suzuki H. Pathogenesis of spontaneous pneumothorax: with special reference to the ultrastructure of emphysematous bullae. Chest 1980; 77: 771-776.

38. Bradley M, Williams C, Walshaw MJ. The value of routine expiratory chest films in the diagnosis of pneumothorax. Arch Emergency Med 1991; 8: 115-116.

39. Schramel FMNH, Wagenaar M, Sutedja TG, Golding RP, Postmus PE. Diagnostiek van pneumothorax niet gediend door aanvullende röntgenopname van de thorax in expiratiestand. Ned Tijdschr Geneeskd 1995; 139: 131-133.
40. Dornhorst AC, Pierce JW. Pulmonary collapse and consolidation: the role of collapse in the production of lung field shadows and the significance of segments in inflammatory lung disease. J Fac Radiol 1954; 5: 276-281.

41. Schramel FMNH, Golding RP, Haakman CDE, Sutedja G, de Jong KA, Postmus PE. Expiratory chest X-rays do not improve visibility of small apical pneumothoraces by enhanced contrast. Eur Respir J 1996; 9: 406409.

42. Flint K, Hillawi AH, Johnson AM. Conservative management of spontaneous pneumothorax. Lancet 1984; i: 687-688.

43. O'Rourke JP, Yee ES. Civilian spontaneous pneumothorax: treatment options and long-term results. Chest 1989; 96: 1302-1306.

44. Hyde L. Spontaneous pneumothorax. Dis Chest 1963; 43: 476-480.

45. Ruckley CV, McCormack RJM. The management of spontaneous pneumothorax. Thorax 1966; 21: 139-144.

46. Seremetis MG. The management of spontaneous pneumothorax. Chest 1970; 57: 65-68.

47. Almind M, Lange P, Viskum K. Spontaneous pneumothorax: comparison of simple drainage, talc pleurodesis and tetracycline pleurodesis. Thorax 1989; 44: 627-630.

48. Light RW, O'Hara VS, Moritz TE, et al. Intrapleural tetracycline for the prevention of recurrent spontaneous pneumothorax. JAMA 1990; 264: 2224-2230.

49. Lippert HL, Lund O, Blegvad S, Larsen HV. Independent risk factors for cumulative recurrence rate after first spontaneous pneumothorax. Eur Respir J 1991; 4: 324331.

50. British Thoracic Society Research Committee. Comparison of simple aspiration with intercostal drainage in the management of spontaneous pneumothorax. Thorax 1993; 48: 430-431.

51. Harvey J, Prescott RJ. Simple aspiration versus intercostal tube drainage for spontaneous pneumothorax in patients with normal lungs. BMJ 1994; 309: 1338-1339.

52. Andrivet P, Djedaini K, Teboul JL, Brochard L, Dreyfuss D. Spontaneous pneumothorax: comparison of thoracic drainage $v s$ immediate or delayed needle aspiration. Chest 1995; 108: 335-340.

53. Videm V, Pillgram-Larsen J, Ellingsen O, Andersen G, Ovrum E. Spontaneous pneumothorax in chronic obstructive pulmonary disease: complications, treatment and recurrences. Eur J Respir Dis 1987; 71: 365-371.

54. Janssen JP, Schramel FMNH, Sutedja TG, Cuesta MA, Oosterhuis W, Postmus PE. Videothoracoscopic appearance of first and recurrent pneumothorax. Chest 1995; 108: 330-334.

55. De Troyer A, Yernault JC, Rodenstein D, Englert M, De Coster A. Pulmonary function in patients with primary spontaneous pneumothorax. Bull Eur Physiopathol Respir 1978; 14: 31-39.

56. Williams MH, Kane C. Pulmonary function in patients who have recovered from spontaneous pneumothorax. Dis Chest 1965; 47: 153-156.

57. Lange P, Mortensen J, Groth S. Lung function 22-35 years after treatment of idiopathic spontaneous pneumothorax with talc poudrage or simple drainage. Thorax 1988; 43: 559-561.

58. Pawlowicz A, Droszcz W. Pulmonary function and alpha $_{1}$-antitrypsin levels in patients after so-called idiopathic spontaneous pneumothorax. Bull Eur Physiopathol Respir 1987; 23: 1-4.

59. Snider GL. Emphysema: the first two centuries and 
beyond. A historical overview with suggestions for future research. Part 1. Am Rev Respir Dis 1992: 146: 1334-1344.

60. Viegi G, Paoletti P, Prediletto R, et al. Carbon monoxide diffusing capacity, other indices of lung function and respiratory symptoms in a general population sample. Am Rev Respir Dis 1990; 141: 1033-1039.

61. Verbeken EK, Cauberghs M, Mertens I, Clement J, Lauwerijns JM, van de Woestijne KP. The senile lung. Comparison with normal and emphysematous lungs: structural aspects. Chest 1992; 101: 793-799.

62. Verbeken EK, Cauberghs M, Mertens I, Clement J, Lauwerijns JM, van de Woestijne KP. The senile lung. Comparison with normal and emphysematous lungs: functional aspects. Chest 1992; 101: 800-809.

63. Olsen PS, Andersen HO. Long-term results after tetracycline pleurodesis in spontaneous pneumothorax. Ann Thorac Surg 1992; 53: 1015-1017.

64. Alfageme I, Moreno L, Huertas C, Vargas A, Hernandez J, Beiztegui A. Spontaneous pneumothorax: long-term results with tetracycline pleurodesis. Chest 1994; 106 : 347-350.

65. Lin CC, Liu CC, Lin CY. Changes in cell population and tumor necrosis factor, interleukin- 6 and interleukin8 in malignant pleural effusions after treatment with intrapleural tetracycline. Am Rev Respir Dis 1993; 147: 1503-1506.

66. Mathur PN, Astoul P, Boutin C. Medical thoracoscopy: technical details. Clin Chest Med 1995; 16: 479-486.

67. Kennedy L, Sahn SA. Talc pleurodesis for the treatment of pneumothorax and pleural effusion. Chest 1994; 106 : $1215-1222$.

68. Milanez JR, Vargas FS, Tarcisio L, Fernandez A, Jatene A, Light RW. Intrapleural talc for the prevention of recurrent pneumothorax. Chest 1994; 106: 1162-1165.

69. el Khawand C, Marchandise FX, Mayne A, et al. Spontaneous pneumothorax: results of pleural talc therapy using thoracoscopy. Rev Mal Respir 1995; 12 : 275-281.

70. Rodriguez-Panadero F, Segado A, Martin-Juan J, et al. Failure of talc pleurodesis is associated with increased pleural fibrinolysis. Am J Respir Crit Care Med 1995; 151: 785-790.

71. Rinaldo JE, Owens GR, Roger RM. Adult respiratory distress syndrome following intrapleural instillation of talc. J Thorac Cardiovasc Surg 1983; 85: 523-526.

72. Bouchema A, Chastre J, Gaudichet A, Soler P, Gilbert C. Acute pneumonitis with bilateral pleural effusion after talc pleurodesis. Chest 1984; 86: 795-797.

73. Research Committee of the British Thoracic Association and the Medical Research Council Pneumoconiosis Unit. A survey of long-term effects of talc and kaolin pleurodesis. Br J Dis Chest 1979; 73: 285-288.

74. Gaensler EA. Partial pleurectomy for recurrent spontaneous pneumothorax. Surg Gynecol Obstet 1956; 102: 293-308.

75. Askew AR. Parietal pleurectomy for recurrent pneumothorax. Br J Surg 1976: 63: 203-205.

76. Getz SB, Beasley WE. Spontaneous pneumothorax. Am J Surg 1983; 145: 823-827.

77. Weeden D, Smith GH. Surgical experience in the management of spontaneous pneumothorax, 1972-1982. Thorax 1988; 38: 737-743.

78. Elfeldt RJ, Schröder D, Meinicke O. Spontanpneumothorax: Überlegungen zur Ätiologie und Therapie. Chirurg 1991; 62: 540-546.

79. Krasnik M, Stimpel H. Treatment of primary spontaneous pneumothorax with intrapleural tetracycline instillation or thoracotomy. Scand J Thorac Cardiovasc Surg 1993; 27: 49-51
80. Cannon WB, Vierra MA, Cannon A. Thoracoscopy in spontaneous pneumothorax. Ann Thorac Surg 1993; 56: 686-687.

81. Yamaguchi A, Shinonega M, Tatebe S, Souma T, Tsuchida M, Saito A. Thoracoscopic stapled bullectomy supported by suturing. Ann Thorac Surg 1993; 56: 691-693.

82. Kaiser LR. Video-assisted thoracic surgery: current state of the art. Ann Surg 1994; 220: 720-734.

83. Thies J, Elfeldt RJ, Schröder DW, Fandrich F. Langzeitergebnisse nach thorakoskopischer Lungenzystenabtragung. Zentralbl Chir 1994; 119: 612-615.

84. Schippers E, Tittel A, Troung S, Schumplick V. Videothoracoskopische Therapie des Spontanpneumothorax: technik und erste Ergebnisse. Chirurg 1994; 65: 722-725.

85. Waller DA, Forty J, Morritt GN. Video-assisted thoracoscopic surgery versus thoracotomy for spontaneous pneumothorax. Ann Thorac Surg 1994; 58: 372-377.

86. Elfeldt RJ, Thies J, Schroder DW. Thoracoscopic resection of parenchymal blebs in spontaneous pneumothorax. Scand J Thor Cardiovasc Surg 1994; 29: 75-78.

87. Ellman BR, Ferrante JW, Tiedemann RN. Thoracoscopy for spontaneous pneumothorax 2.10 version with bleb stapling and pleurectomy. Am Surg 1995; 61: 102-105.

88. Liu HP, Lin PJ, Hsieh MJ, Chang JP, Chang CH. Thoracoscopic surgery as a routine procedure for spontaneous pneumothorax: results from 82 patients. Chest 1995; 107: 559-562.

89. Naunheim KS, Mack MJ, Hazelrigg SR, et al. Safety and efficacy of video assisted thoracic surgical techniques for the treatment of spontaneous pneumothorax. J Thorac Cardiovasc Surg 1995; 109: 1198-1203.

90. Yim AP, Ho JK. One hundred consecutive cases of video-assisted thoracoscopic surgery for primary spontaneous pneumothorax. Surg Endoscopy 1995; 9: 332-336.

91. Hürtgen M, Buhr J, Kluth D. Thoracosckopische Operation des sekundaren Spontanpneumothorax. Chirurg 1995; 66: 994-996.

92. De Giacomo T, Rendina EA, Venuta F, Ciriaco P, Lena A, Ricci C. Video-assisted thoracoscopy in the management of recurrent spontaneous pneumothorax. Eur $J$ Surg 1995; 161: 227-230.

93. Weatherford DA, Stephenson JE, Taylor SM, Blackhurst D. Thoracoscopy versus thoracotomy: indications and advantages. Am Surg 1995; 61: 83-86.

94. Schramel FMNH, Sutedja TG, Braber JCE, van Mourik JC, Postmus PE. Cost-effectiveness of video-assisted thoracoscopic surgery versus conservative treatment for first time or recurrent spontaneous pneumothorax. Eur Respir J 1996; 9: 1821-1825.

95. Deslauriers J. The management of spontaneous pneumothorax. Can J Surg 1994; 37: 182.

96. Wakabayashi A, Brenner M, Wilson AF, Tadir Y, Berns M. Thoracoscopic treatment of spontaneous pneumothorax using carbon dioxide laser. Ann Thorac Surg 1990; 50: 786-790.

97. Lewis RJ, Caccavale RJ, Sissler GE. VATS argon beam coagulator treatment of diffuse end-stage bilateral bullous disease of the lung. Ann Thorac Surg 1993; 55: 1394-1399.

98. Torre M, Grassi M, Nerli FP, Mardi M, Belloni PA. Nd-YAG laser pleurodesis via thoracoscopy: endoscopic therapy in spontaneous pneumothorax, Nd-YAG laser pleurodesis. Chest 1994; 106: 338-341.

99. Metersky ML, Colt HL, Olson LK, Sharks TG. AIDSrelated spontaneous pneumothorax: risk factors and treatment. Chest 1995; 108: 946-951. 